\title{
PENGARUH MODEL QUANTUM LEARNING TERHADAP PENINGKATAN HASIL BELAJAR IPA SISWA
}

\author{
K. Arma Ayu Indrayani, N. M. Pujani, N. L. Pande Latria Devi \\ Program Studi S1 Pendidikan IPA \\ Universitas Pendidikan Ganesha \\ Singaraja, Indonesia
}

e-mail: \{ayu.indrayani, made.pujani, latria.devi\}@undiksha.ac.id

\begin{abstract}
Abstrak
Penelitian ini bertujuan untuk mendeskripsikan profil hasil belajar IPA siswa di SMP Negeri 4 Singaraja dan menganalisis perbedaan hasil belajar IPA antara siswa yang mengikuti model Quantum Learning dengan siswa yang mengikuti model pembelajaran konvensional di SMP Negeri 4 Singaraja. Penelitian ini merupakan penelitian eksperimen dengan rancangan non-equivalent pre test-post test control group design. Populasi penelitian adalah seluruh siswa kelas VII berjumlah 348 orang. Sampel penelitian dipilih 2 kelas yaitu kelas VII SMP Negeri 4 Singaraja. Sebanyak 62 siswa yang ditentukan dengan teknik random sampling. Penelitian ini melibatkan 3 variabel yaitu 1) variabel bebas adalah model pembelajaran, 2) variabel terikat adalah hasil belajar kognitif IPA, dan 3) variabel kovariat adalah pengetahuan awal siswa. Pengumpulan data menggunakan instrumen tes objektif diperluas. Untuk mengetahui adanya perbedaan hasil belajar IPA siswa antara kelompok eksperimen dengan kelompok kontrol digunakan uji ANAKOVA dengan taraf sig.< 0,05. Hasil penelitian menunjukkan bahwa hasil belajar IPA siswa SMP Negeri 4 Singaraja yang belajar dengan MQL berkualifikasi tinggi $(\bar{x}=84)$, sedangkan yang belajar dengan MPK nilai rata-rata juga berkualifikasi tinggi $(\overline{\mathrm{x}}=71)$. Terdapat perbedaan yang signifikan hasil belajar antara siswa yang belajar model Quantum Learning dan siswa yang belajar dengan model pembelajaran konvensional $(F=0,000$ sig. $<0,05)$. Hasil belajar IPA siswa dengan model Quantum Learning lebih baik dari pada model pembelajaran konvensional $\left|\mu_{1}-\mu_{2}\right|>2,58$
\end{abstract}

Kata Kunci: Model Quantum Learning, Model Konvensional, Hasil Belajar IPA

\begin{abstract}
This study was aimed to describe the profile of science learning outcomes of students in SMP Negeri 4 Singaraja and analyzed the results of science learning between students who obtains the model of Quantum Learning with students who obtains the conventional learning model in SMP Negeri 4 Singaraja. This research was an experimental research with non-equivalent pre test-post test group control design. The study population were 348 students of seventh grade. The sample of research was 2 classes that chosen from seventh grade of SMP Negeri 4 Singaraja. 62 students determined by random sampling technique. This research involved 3 variables that were 1) independent variable is model of learning, 2) variable is result of cognitive learning of IPA, and 3) variable of covariat is initial knowledge of student. Expanded objective tes used as data collection from. Additionally, to observed differences in students' ability between the experimental group and the group the ANACOVA with sig level. $<0.05$. The results showed that the learning outcomes of science students of SMP Negeri 4 Singaraja who studied with high qualified MQL $\left(x^{-}=84\right)$, whereas those who studied with MPK average countries were also highly qualified $\left(x^{-}=71\right)$. A significant experience of learning outcomes between students learning the Quantum Learning model and students learning with conventional learning models ( $F=0,000$ sig. $<0.05)$. The result of science learning of students with Quantum Learning model is better than conventional learning model $\left|\mu_{1}-\mu_{2}\right|>2,58$
\end{abstract}

Keywords: Quantum Learning Model, Conventional Model, Science Learning Outcomes 


\section{PENDAHULUAN}

Pendidikan memiliki peranan yang sangat penting dalam kehidupan berbangsa dan bernegara. Pendidikan merupakan usaha sadar untuk menuntun individu dalam menentukan tujuan hidupnya. Pendidikan juga berfungsi menyiapkan individu menjadi anggota masyarakat yang memiliki kemampuan mengadakan hubungan timbal balik dengan lingkungan sosial, budaya, dan alam sekitar, serta dapat mengembangkan kemampuan lebih lanjut dalam dunia kerja atau pendidikan tinggi (Winataputra, 2002).

Pemerintah Indonesia telah menggalakkan berbagai upaya untuk meningkatkan kualitas sumber daya manusia dalam pendidikan. Upaya tersebut terlihat dari adanya penyempurnaan kurikulum dari Kurikulum Tingkat Satuan Pendidikan (KTSP) menjadi Kurikulum 2013. Kurikulum 2013 dirancang untuk memperkuat kompetensi siswa dari sisi pengetahuan, keterampilan, dan sikap (Kemendikbud, 2016). Pembelajaran Kurikulum 2013 menerapkan pendekatan ilmiah (scientific approach) pada semua mata pelajaran termasuk salah satunya mata pelajaran IPA.

IPA merupakan cabang ilmu pengetahuan yang berawal dari fenomena alam (Kemendikbud, 2016). IPA adalah pengetahuan yang rasional dan objektif tentang alam semesta dengan segala isinya (Samatowa, 2011). IPA membahas tentang gejala-gejala alam yang disusun secara sistematis yang didasarkan pada hasil percobaan dan pengamatan yang dilakukan manusia (Trianto, 2010). Tujuan diselenggarakannya pembelajaran IPA di SMP/Mts yang disebutkan dalam Permendiknas Nomor 22 Tahun 2006 yaitu, 1) mengembangkan pemahaman tentang berbagai macam gejala alam, konsep dan prinsip IPA yang bermanfaat dan dapat diterapkan dalam kehidupan sehari-hari, 2) mengembangkan rasa ingin tahu, sikap positif dan kesadaran terhadap adanya hubungan yang saling mempengaruhi antara IPA, lingkungan, teknologi dan masyarakat, 3) melakukan inkuiri ilmiah untuk menumbuhkan kemampuan berpikir, bersikap dan bertindak ilmiah serta berkomunikasi, dan 4) meningkatkan pengetahuan, konsep dan keterampilan IPA sebagai dasar untuk melanjutkan pendidikan kejenjang selanjutnya. Berdasarkan tujuan di atas, pendidikan IPA diharapkan dapat menjadi sarana bagi peserta didik untuk mempelajari diri sendiri dan alam sekitar, serta lebih lanjut dapat meningkatkan kualitas pendidikan di Indonesia.

Kenyataanya, berbagai upaya yang dilakukan pemerintah tersebut, belum mampu meningkatkan kualitas pendidikan di Indonesia. Hal tersebut terlihat dari hasil Program for International Student Assessment PISA (2015) menunjukkan bahwa Indonesia berada pada peringkat 64 dari 72 negara dengan skor rata-rata 403 (BBC, 2015). IPA merupakan salah satu bidang keilmuan yang diujikan dalam PISA. Berdasarkan hasil PISA di atas, rendahnya peringkat siswa Indonesia dalam bidang IPA merupakan salah satu indikator bahwa ada permasalahan dalam penerapan mata pelajaran IPA di sekolah.

Masalah senada juga ditemui pada hasil nilai Ujian Nasional (UN) tingkat SMP/Mts di Bali tahun 2017. Hasil belajar siswa masih tergolong rendah, terlihat pada rata-rata nilai Ujian Nasional (UN) tingkat SMP/Mts di Bali tahun 2017 menunjukkan penurunan dari tahun 2016. Hasil rekapitulasi Kemdikbud Kabupaten Buleleng terlihat bahwa tahun 2016 ratarata nilai UN IPA sebesar 58,11 sedangkan pada tahun 2017 mengalami penurunan drastis yaitu sebesar 50,45 (Kemdikbud, 2017). Dari keempat mata pelajaran yang di-UN-kan, mata pelajaran IPA mengalami penurunan yang paling besar. Fakta ini menunjukkan bahwa kualitas hasil belajar siswa pada mata pelajaran IPA masih tergolong rendah.

Hasil belajar merupakan kemampuankemampuan yang dimiliki oleh siswa setelah menerima pengalaman belajar dari guru (Moedjiono dan Dimyati, 2006). Hasil belajar siswa dipengaruhi oleh perubahan tingkah laku yang meliputi atas tiga aspek hasil belajar. Taksonomi Bloom (dalam Katminingsih, 2012) membagi tiga aspek hasil belajar, pertama adalah aspek kognitif. Aspek ini meliputi kemampuan menyatakan kembali konsep atau prinsip yang telah dipelajari dan kemampuan intelektual. 
Aspek kognitif dibatasi pada mengingat $\mathrm{C} 1$, memahami C2, mengaplikasikan C3, dan menganalisis C4. Aspek kedua yaitu afektif, aspek ini meliputi pandangan atau pendapat dan sikap atau nilai. Aspek ketiga yaitu psikomotorik, berhubungan dengan kerja otot atau gerak yang sudah tertuang dalam kurikulum.

Berkaitan dengan rendahnya hasil belajar menunjukkan adanya masalah pada proses pembelajaran. Sanjaya (2009) mengatakan dalam proses pembelajaran guru hanya menyajikan apa yang ada dibuku dan masih secara konvensional tanpa memperhatikan hasil belajar yang diharapkan. Model pembelajaran konvensional pada umumnya memiliki kekhasan tertentu, misalnya lebih mengutamakan hafalan dari pada pengertian, mengutamakan hasil dari pada proses, dan pengajaran berpusat kepada guru (Rohimah, 2012). Santyasa (2004) menyatakan faktor penyebab rendahnya pemahaman siswa tidak diperhatikan dalam pembelajaran konvensional yaitu, pembelajaran sering mengabaikan strategi perubahan konseptual dan pembelajaran sering mengabaikan pengetahuan awal siswa. Pengetahuan awal dapat berpengaruh langsung dan tak langsung terhadap proses pembelajaran. Secara langsung pengetahun awal dapat mempermudah proses pembelajaran dan mengarahkan hasil-hasil belajar yang baik, sedangkan secara tidak langsung pengetahuan awal dapat mengoptimalkan kejelasan materi-materi pelajaran dan meningkatkan efisiensi penggunaan waktu belajar dan pembelajaran (Santyasa, 2004). Model pembelajaran hendaknya dirancang sedemikian rupa tidak hanya merupakan suatu transfer pengetahuan saja dari guru kepada siswa melainkan sebaliknya adanya timbal balik antara siswa dengan guru dan siswa dengan siswa agar pembelajaran dapat bermakna dan menyenangkan. Model pembelajaran juga merupakan hal yang sangat penting digunakan dalam upaya meningkatkan hasil belajar siswa, maka dibutuhkan model pembelajaran yang menciptakan suasana yang menyenangkan (Slavin, 2011). Hal ini bertujuan untuk memberikan kesempatan seluas-luasnya kepada siswa guna mengekspresikan gagasan dan pikirannya agar menjadi manusia yang berkualitas sesuai dengan tujuan pendidikan nasional. Salah satu pembelajaran yang dapat menciptakan suasana yang menyenangkan yaitu model Quantum Learning.

Model Quantum Learning adalah salah satu model pembelajaran yang berisi petunjuk, strategi, proses pembelajaran yang dibuat menyenangkan, dan bermakna (Agusnanto, 2013). Model Quantum learning juga memberikan kesadaran bagi para pembelajar khususnya siswa tentang pentingnya belajar. Tumbuhnya kesadaran siswa tersebut salah satunya dikarenakan adanya AMBAK (Apa Manfaat BAgiKu). AMBAK adalah motivasi yang didapat dari pemilihan secara mental antara manfaat dan akibat-akibat suatu keputusan (Porter dan Hernacki, 2015). Hal ini menjelaskan bahwa dalam setiap diri siswa akan tertanam kekuatan berupa dorongan untuk melakukan sesuatu karena dalam pembelajaran menjanjikan adanya manfaat bagi dirinya atau dapat dikatakan munculnya kekuatan AMBAK. Selain itu, desain suasana pembelajaran yang demokratis, saling membelajarkan dan menyenangkan pun memberikan peluang lebih besar dalam memberdayakan potensi siswa secara optimal sehingga pembelajaran yang kurang menarik dapat diatasi karena siswa diajak belajar dalam suasana yang lebih nyaman dan menyenangkan, serta lebih bebas dalam menemukan berbagai pengalaman baru dalam belajarnya.

Beberapa penelitian mengemukakan bahwa model Quantum Learning memberikan dampak positif bagi hasil belajar siswa. Penelitian yang dilakukan oleh Yusuf (2014) menunjukkan hasil belajar IPA siswa yang mengikuti model pembelajaran Quantum Learning lebih baik dari pada model pembelajaran konvensional. Penelitian tersebut menunjukkan bahwa model Quantum Learning dapat memberikan kontribusi kearah yang positif terhadap sikap dan hasil belajar siswa. Hal serupa juga ditunjukkan oleh Sari (2013) menunjukan bahwa siswa yang mengikuti model Quantum Learning memiliki hasil belajar dan aktivitas belajar siswa yang lebih tinggi dari pada yang 
mengikuti pembelajaran konvensional. Penelitian tersebut menunjukkan bahwa model Quantum Learning berpengaruh positif terhadap hasil belajar dan aktivitas belajar siswa.

Model

Quantum Learning

memberikan kesempatan kepada siswa untuk membangun pengetahuan, pemahaman, dan daya ingat siswa akan bertahan dalam jangka waktu yang panjang, serta membuat belajar sebagai suatu proses yang menyenangkan dan bermanfaat. Melalui model Quantum Learning diharapkan dapat meningkatkan hasil belajar IPA. Atas dasar paparan di atas, penulis melakukan penelitian dengan judul "Pengaruh Model Quantum Learning Terhadap Peningkatan Hasil Belajar IPA Siswa".

\section{METODE PENELITIAN}

Penelitian ini merupakan penelitian quasi experiment (eksperimen semu) dengan menggunakan desain Nonequivalent Control Group Design. Rancangan penelitian ini melibatkan dua kelompok yaitu kelompok eksperimen dan kelompok kontrol. Kedua kelompok mendapat perlakuan yang sama dari segi pemberian materi, tetapi berbeda dalam perlakuan pembelajaran. Pada kelompok eksperimen pembelajaran di kelas menerapkan strategi pembelajaran Quantum Learning, sedangkan pada kelompok kontrol pembelajaran di kelas menerapkan pembelajaran konvensional. Pemberian pretest dilakukan pada awal penelitian dan pemberian posttest dilakukan pada akhir penelitian pada kedua kelompok. Populasi dalam penelitian ini adalah siswa kelas VII SMP Negeri 4 Singaraja tahun pelajaran 2017/2018, yang terdiri dari 11 kelas. Dalam penelitian ini sampel yang dipergunakan adalah dua kelas. Teknik pengambilan sampel pada penelitian ini dilakukan dengan teknik random sampling, yang dirandom adalah kelas. Kelas dibentuk sebagaimana telah terbentuk sebelumnya tanpa campur tangan peneliti, hal ini dilakukan untuk mengurangi kemungkinan dari pengaruhpengaruh yang mungkin terjadi apabila subjek mengetahui dirinya dilibatkan dalam eksperimen. Berdasarkan teknik random sampling yang telah dilakukan secara acak di SMP Negeri 4 Singaraja telah ditetapkan bahwa kelas eksperimen adalah kelas VII B5 yang berjumlah 31 siswa dan kelas kontrol adalah kelas VII B6 yang berjumlah 31 siswa.

Instrumen pengumpulan data hasil belajar berupa instrumen tes tertulis berbentuk pilihan ganda diperluas (multiple choice test with written justification) berupa tes sebanyak 20 item yang tersebar dalam jenjang kognitif mengetahui (C1), memahami (C2), mengaplikasikan (C3), dan menganalisis (C4). Jumlah butir soal yang digunakan 20 butir. Kriteria penilian tes hasil belajar tipe pilihan ganda diperluas menggunakan rubrik dengan skor minimal dari masing-masing butir tes pemahaman konsep adalah 0 dan skor maksimalnya adalah 3.

Variabel penelitian adalah segala sesuatu yang berbentuk apa saja oleh peneliti untuk dipelajari sehingga diperoleh informasi tentang hal tersebut kemudian diambil kesimpulannya (Sugiyono, 2011). penelitian ini melibatkan variabel bebas, variabel terikat dan variabel kovariat. Variabel bebas dalam penelitian ini adalah model Quantum Learning yang dikenakan pada kelompok eksperimen dan pembelajaran konvensional yang dikenakan sebagai kelompok kontrol, Variabel terikat dalam penelitian ini adalah hasil belajar IPA siswa, dan variabel kovariat dalam penelitian ini adalah pengetahuan awal siswa. Dalam penelitian ini data yang diperlukan adalah data hasil belajar siswa pada materi interaksi makhluk hidup dengan lingkungan.

Tes hasil belajar IPA yang digunakan dalam penelitian ini disusun oleh peneliti dibawah bimbingan dari dosen pembimbing. Tes hasil belajar IPA berjumlah 35 butir soal. Sebelum tes tersebut digunakan terlebih dahulu tes diuji validitas, daya beda, tingkat kesukaran, dan reliabilitasnya. Dari hasil uji coba terdapat 19 butir soal yang diterima, 6 butir soal direvisi, 10 butir soal gugur, jadi jumlah soal untuk uji intrumen adalah 20 soal dengan mengambil 1 soal yang akan direvisi. Sebelum dilakukan uji hipotesis terlebih dahulu dilakukan uji persyaratan analisis terhadap data hasil penelitian. Uji 
persyaratan analisis dilakukan untuk memperoleh fakta apakah data memenuhi prasyarat homogenitas, normalitas dan linearitas. Untuk mengetahui apakah sebaran data hasil belajar IPA siswa masing-masing kelompok berdistribusi normal atau tidak. Uji homogenitas varians dilakukan untuk menunjukkan bahwa perbedaan yang terjadi pada uji hipotesis benar-benar terjadi akibat adanya perbedaan antar kelompok, bukan sebagai akibat perbedaan dalam kelompok. Uji homogenitas varians dilakukan dengan menggunakan uji $\mathrm{F}$. Uji linieritas dilakukan untuk mengetahui apakah dua variabel mempunyai hubungan yang linier atau tidak secara signifikan. Untuk menguji hipotesis penelitian ini adalah uji ANAKOVA satu jalur dan dilanjutkan dengan pengujian LSD.

\section{HASIL DAN PEMBAHASAN HASIL PENELITIAN}

Profil hasil belajar IPA yang dipaparkan mencangkup beberapa hal yang meliputi distribusi frekuensi, nilai rata-rata, dan standar deviasi hasil belajar IPA pada siswa kelas VII SMP Negeri 4 Singaraja. Jumlah siswa pada kelompok eksperimen
31 orang dan jumlah siswa pada kelompok kontrol 31 orang.

Perbedaan hasil belajar antara model Quantum Learning (MQL) dan model pembelajaran konvensional (MPK) digunakan empat uji analisis meliputi 1) uji normalitas, 2) uji homogenitas, 3) uji linieritas, dan 4) uji hipotesis. Uji lanjut dalam penelitian ini dilakukan uji signifikansi skor rata-rata antar kelompok yang menggunakan Least Significant Difference (LSD). Kelompok yang diuji signifikansi perbedaan skor rata-rata hasil belajar IPA adalah kelompok kontrol dan eksperimen.

Berdasarkan data nilai hasil belajar IPA yang dikumpulkan diperoleh nilai hasil belajar IPA siswa SMP Negeri 4 Singaraja berkisar antara 75 sampai 91 untuk siswa kelompok eksperimen dan 61 sampai 85 untuk kelompok kontrol. Data nilai hasil belajar IPA yang diperoleh dapat dilihat pada Tabel 1 profil distribusi frekuensi dan persentase siswa berdasarkan nilai pengetahuan awal siswa dan hasil belajar IPA. Tabel distribusi frekuensi dan persentase berpedoman pada konversi Penilaian Acuan Patokan (PAP) tersebut disajikan pada Tabel 1.

Tabel 1. Profil Distribusi Frekuensi dan Persentase Nilai Pretest dan Posttest Hasil Belajar IPA

\begin{tabular}{|c|c|c|c|c|c|c|c|c|c|}
\hline \multirow{3}{*}{ Skor } & \multirow{3}{*}{ Kategori } & \multicolumn{4}{|c|}{ MQL } & \multicolumn{4}{|c|}{ MPK } \\
\hline & & \multicolumn{2}{|c|}{ Pretest } & \multicolumn{2}{|c|}{ Posttest } & \multicolumn{2}{|c|}{ Pretest } & \multicolumn{2}{|c|}{ Posttest } \\
\hline & & Fo & $\%$ & Fo & $\%$ & fo & $\%$ & Fo & $\%$ \\
\hline $\begin{array}{c}85- \\
100 \\
\end{array}$ & Sangat baik & - & - & 18 & 58,06 & - & - & 5 & 16,12 \\
\hline $71-84$ & Baik & - & - & 13 & 41,93 & - & - & 17 & 54,83 \\
\hline $65-70$ & Cukup & - & - & - & - & - & - & 8 & 25,80 \\
\hline $50-64$ & Kurang & 11 & $\begin{array}{c}35,4 \\
8\end{array}$ & - & - & 13 & 41,93 & - & - \\
\hline $0-49$ & $\begin{array}{l}\text { Sangat } \\
\text { kurang }\end{array}$ & 20 & $\begin{array}{c}64,5 \\
1\end{array}$ & - & - & 18 & 58,06 & - & - \\
\hline \multicolumn{2}{|r|}{ Total } & 31 & 100 & 31 & 100 & 31 & 100 & 31 & 100 \\
\hline \multicolumn{2}{|c|}{ Rata-rata } & \multicolumn{2}{|c|}{47,04} & \multicolumn{2}{|c|}{84} & \multicolumn{2}{|c|}{47,20} & \multicolumn{2}{|c|}{71} \\
\hline \multicolumn{2}{|c|}{ Standar Deviasi } & \multicolumn{2}{|c|}{7,17} & \multicolumn{2}{|c|}{4,38} & \multicolumn{2}{|c|}{7,34} & \multicolumn{2}{|c|}{6,51} \\
\hline
\end{tabular}

Keterangan : MQL: Model Quantum Learning, MPK:Model Pembelajaran Quantum Learning

Berdasarkan Tabel 1 dapat diketahui bahwa nilai rata-rata hasil belajar IPA untuk kelompok model Quantum Learning $(\mathrm{n}=31)$ menunjukkan bahwa nilai rata-rata pretest sebesar 47,04 dan postest sebesar 84 memiliki nilai kualifikasi tinggi dan model pembelajaran konvensional $(n=31)$ nilai rata-rata pretest sebesar 47,20 dan nilai rata-rata posttest sebesar 71 memiliki nilai kualifikasi tinggi. Jadi nilai rata-rata 
kelompok model Quantum Learning dan kelompok model pembelajaran konvensional memiliki kategori sama yaitu tinggi, namun dilihat dari angkanya bahwa model Quantum Learning lebih tinggi dari model pembelajaran konvensional.

Uji normalitas hasil belajar IPA dapat diketahui bahwa pada kelompok eksperimen MQL uji normalitas pretest 0,307 dan posttest 0,365 . Pada kelompok kontrol MPK uji normalitas pretest 0,465 dan posttest 0,107 . Jadi dari data kelompok MQL dan kelompok MPK nilai singnifikansi berada diatas 0,05 (sig.>0,05). Hal ini menunjukkan bahwa sebaran data analisis berasal dari populasi yang berdistribusi normal.

Hasil uji homogenitas varian antar kelompok MQL dan MPK untuk data skor hasil belajar IPA menunjukkan angka-angka signifikansi statistik levene lebih besar dari 0,05 . Hasil uji homogenitas pretest sebesar 0,433 dan posttest sebesar 0,124. Ini berarti varian data skor hasil belajar IPA antara kelompok eksperimen dan kelompok kontrol adalah homogen.

Uji linieritas menggunakan Test of Linearity pada taraf signifikansi 0,05 . Hasil belajar pada dua variabel menunjukkan angka-angka statistik lebih kecil dari 0,05, maka data tersebut dikatakan mempunyai hubungan yang linear.

Hipotesis yang diajukan pada penelitian ini adalah terdapat perbedaan hasil belajar IPA antara siswa yang belajar dengan model pembelajaran MQL dan siswa yang belajar dengan MPK menunjukkan bahwa hasil perhitungan ANCOVA dari nilai pengetahuan awal dan model pembelajaran diperoleh angka signifikansi lebih kecil dari 0,05. Oleh karena itu, hipotesis nol yang menyatakan bahwa tidak terdapat perbedaan hasil belajar antara kelompok siswa yang belajar dengan MQL antara kelompok siswa yang belajar dengan MPK. Dengan demikian, terdapat perbedaan yang singnifikan antara hasil belajar kelompok siswa yang belajar MQL dengan kelompok siswa yang belajar MPK. Sebagai tindak lanjut pengujian hipotesis dengan menggunakan metode Least Significant Difference (LSD). Pada angka signifikansi 0,05 , untuk variabel terikat hasil belajar siswa diperoleh batas penolakan adalah $L S D=2,58$. Kriteria yang digunakan adalah $\mathrm{H}_{0}$ ditolak jika harga mutlak $\left|\mu_{1}-\mu_{2}\right|>$ LSD yaitu signifikan nilai selisih 9,176 lebih besar dari nilai LSD, maka model Quantum Learning lebih baik dari model pembelajaran konvensional dalam menunjukkan hasil belajar IPA siswa.

\section{PEMBAHASAN}

Berdasarkan analisis profil hasil belajar IPA diperoleh bahwa tingkat hasil belajar IPA siswa kelas VII SMP Negeri 4 Singaraja dilihat dari hasil dari nilai rata-rata kelompok MQL dan MPK memiliki kategori sama yaitu tinggi, namun dilihat dari angkanya bahwa MQL lebih tinggi dari MPK. Dari hasil ANCOVA diketahui bahwa secara statistik terjadi perbedaan yang signifikan antara hasil belajar IPA siswa MQL dengan MPK pada taraf signifikansi 0,05 . Hal ini dapat ditunjukkan dengan taraf signifikansi lebih kecil dari 0,05. Siswa yang mengikuti MQL hasil belajar IPA yang lebih baik dari pada siswa yang mengikuti MPK yang juga diperkuat dengan hasil perhitungan LSD yang diperoleh batas penolakan sebesar 2,58.

Proses pembelajaran pada penelitian ini menggunakan materi interaksi mahluk hidup dengan lingkungannya yang terdiri dari tujuh kali pertemuan. Pada pertemuan pertama melaksanakan pretest hasil belajar IPA dan pertemuan ketujuh melaksanakan postest hasil belajar IPA. Pada kelompok kontrol diberikan perlakuan berupa pembelajaran konvensional (MPK) sedangkan pada kelompok eksperimen diberikan perlakuan berupa model Quantum Learning (MQL). Berdasarkan hasil analisis diperoleh bahwa model Quantum Learning memberikan pengaruh positif terhadap hasil belajar IPA siswa. Hal ini dikarenakan pada proses pembelajaran dengan MQL siswa diberikan kesempatan lebih untuk berpartisipasi aktif dalam kegiatan diskusi di kelas, mengeksplorasi ide-ide yang dimiliki untuk menyelesaikan suatu permasalahan, memanfaatkan modalitas (video, musik, games, dan gambar) untuk mengkontruksi pengetahuan siswa, mempresentasikan hasil diskusi dan diberikan latihan lebih lanjut untuk meningkatkan pemahaman dan keterampilan dalam menyelesaikan tugas- 
tugas yang diberikan. Selain itu, pada saat proses pembelajaran berlangsung guru memberikan penghargaan kepada siswa yang terlibat aktif selama proses pembelajaran seperti memberikan pujian, tambahan poin, tepuk tangan, hadiah berupa alat tulis dan lain sebagainya yang dapat meningkatkan minat belajar siswa.

Langkah-langkah kegiatan MQL terdiri dari 6 tahap pembelajaran yaitu Tumbuhkan, Alami, Namai, Demonstrasikan, Ulangi, dan Rayakan (TANDUR). Pada tahap Tumbuhkan guru menyiapkan rancangan pembelajaran serta tujuan pembelajaran yang hendak dicapai. Selanjutnya guru memberikan apersepsi motivasi dan membangkitkan rasa ingin tahu siswa terhadap materi yang akan dipelajari dengan cara memberikan contoh permasalahan dalam kehidupan sehari-hari. Pada saat memberikan apersepsi, guru membangkitkan kembali ingatan siswa tentang materi sebelumnya yang terkait dengan materi yang akan dibahas dengan cara memberikan beberapa pertanyaan kepada siswa. Selain itu, guru membentuk siswa menjadi beberapa kelompok sesuai dengan minat belajar yang siswa inginkan misalnya, kelompok belajar sambil menonton video, kelompok belajar sambil mendengarkan musik, dan kelompok belajar sambil praktikum serta memberikan LKS pada masing-masing kelompok.

Pada tahap kedua yaitu tahap Alami, siswa bersama teman kelompoknya mendiskusikan masalah pada LKS. Ketika proses diskusi berlangsung siswa akan saling bertukar informasi dengan teman kelompoknya dalam mencari solusi dan permasalahan pada LKS. Setelah mengamati dan memahami permasalahan yang diberikan, pada tahap Namai siswa diharapkan mampu mengembangkan kemampuannya dalam mengkonstruksi dan membuat keterkaitan antara konsep dari materi yang dibahas.

$$
\text { Selanjutnya }
$$

Demonstrasikan, pada siswa tahap kesempatan untuk menyampaikan hasil diskusi kelompoknya, guru memilih siswa secara acak dalam kelompoknya untuk menyampaikan hasil diskusi. Ketika mempresentasikan hasil diskusi, setiap siswa memiliki hak untuk menanggapi hasil diskusi teman kelompoknya. Pada tahap Ulangi, siswa dipilih secara acak untuk menyempaikan kesimpulan dari materi yang sudah dibahas, memberikan tugas rumah berupa latihan soal untuk memantapkan pemahaman siswa dan menekankan kembali konsep-konsep penting yang akan dibahas pada materi selanjutnya. Pada tahapan terakhir yaitu tahapan Rayakan, guru memberikan hadiah kepada siswa yang aktif selama proses pembelajaran baik secara individu maupun berkelompok yang akan membuat siswa lebih termotivasi untuk mengikuti proses pembelajaran.

Berdasarkan hasil temuan selama melaksanakan penelitian, proses pembelajaran dengan menggunakan tahapan-tahapan MQL mampu membuat: 1) minat dan motivasi belajar siswa meningkat karena siswa diberikan kesempatan untuk mengeksplorasi kemampuannya sendiri, 2) siswa lebih berpartisipasi aktif dalam proses pembelajaran seperti lebih berani dalam mengemukakan pendapat ataupun pertanyaan, 3) siswa memiliki kesempatan lebih untuk mengembangkan kemampuannya dengan dukungan video, musik, praktikum, games, dan gambar.

$$
\text { Dilihat dari segi suasana }
$$

pembelajaran di kelas, siswa yang dibelajarkan dengan MQL suasanannya lebih kondusif terutama saat kegiatan diskusi kelompok. Melalui diskusi kelompok siswa dapat bertukar pikiran, berdiskusi, serta curah pendapat dengan teman dalam kelompok yang disertai dengan pemberian bimbingan, sehingga mereka bisa lebih memaknai dan memahami pembelajaran yang telah dilaksanakan. Sesuai dengan pendapat Deporter dan Hernacki (2015) berpendapat bahwa: "Quantum Learning adalah kiat, petunjuk, strategi dan seluruh proses belajar yang dapat mempertajam pemahaman dan daya ingat, serta membuat belajar sebagai suatu proses yang menyenangkan dan bermanfaat". Pada kegiatan diskusi kelompok terjalin diskusi yang baik antara siswa dengan siswa maupun siswa dengan guru mampu meningkatkan hasil belajar IPA, mengingat MQL lebih berorientasi pada siswa akan didapatkan berbagai manfaat antara lain: bersikap positif, meningkatkan motivasi, 
keterampilan belajar seumur hidup, kepercayaan diri, dan hasil belajar yang meningkat (Deporter dan Hernacki, 2015).

Berdasarkan penelitian yang dilakukan juga menghasilkan hasil yang sama seperti penelitian yang dilakukan oleh Pratiwi (2017) penelitian yang berjudul Pengaruh Penerapan Metode Quantum Learning berbantuan peta konsep Terhadap Hasil Belajar Siswa. Hasil penelitian menunjukkan bahwa penggunaan model pembelajaran Quantum Learning berbantuan peta konsep dapat meningkatkan hasil belajar siswa, ini terlihat pada hasil belajar IPA siswa yang mengikuti model pembelajaran quantum learning berbantuan peta konsep termasuk dalam kategori baik dengan nilai tertinggi pada kelompok eksperimen yaitu 93,3 dan nilai terendah yaitu 60. Berdasarkan hasil penelitian disimpulkan bahwa penggunaan model pembelajaran Quantum Learning meningkatkan hasil belajar. Selain itu, menurut penelitian Cahyani (2015) dalam penelitiannya yang berjudul Pengaruh Model Quantum tipe VAK (Visual, Auditori, Kinestetik) Berbantuan Geogebra terhadap Kemampuan Berpikir Kritis Matematika Siswa Kelas XI SMA Negeri 1 Gianyar. Berdasarkan hasil penelitian menunjukkan bahwa Model Quantum tipe VAK (Visual, Auditori, Kinestetik) berbantuan Geogebra memberikan dampak positif terhadap kemampuan berpikir kritis dan model Quantum tipe VAK (Visual, Auditori, Kinestetik) lebih baik dari pada model konvensional, dan sejalan dengan penelitian Wijayanti (2013) nilai rata-rata hasil belajar IPA pada kelas eksperimen 84,71 dan kelompok kontrol 81,32. Demikian pula hasil analisis menunjukkan terdapat perbedaan yang signifikan hasil belajar IPA siswa yang dibelajarkan melalui model pembelajaran kuantum dengan siswa yang dibelajarkan melalui pembelajaran konvensional. Hasil analisis diperoleh nilai $\left(\mathrm{th}_{\text {itung }}=4,29>\mathrm{t}_{\text {tabel }}=2.00\right.$ ). Dengan demikian dapat disimpulkan bahwa model pembelajaran kuantum (quantum learning) berpengaruh terhadap hasil belajar IPA siswa.

Berbeda dengan pembelajaran konvensional, pada proses pembelajaran di sekolah kurang menekankan keaktifan siswa. Langkah-langkah pembelajaran konvensional yaitu, 1) pada awal pembelajaran guru memberikan salam, 2) menyampaikan materi dan tujuan pembelajaran yang ingin dicapai, 3) guru memberikan apersepti kepada siswa dengan menyampaikan materi yang akan dipelajari serta mengaplikasikannya dalam kehidupan sehari-hari, 4) guru menyampaikan materi dan memberikan pertanyaan, 5) siswa menjawab pertanyaan dan mempresentasikan hasilnya di depan kelas, 6) guru memberikan konfirmasi untuk meluruskan pemahaman siswa yang masih keliru, dan 7) guru memberikan soal evaluasi untuk pekerjaan di rumah.

$$
\text { Pada tahap pembelajaran }
$$

konvensional, kemampuan hasil belajar IPA dilatih pada tahap kelima. Guru memberikan kesempatan kepada siswa untuk menjawab soal dan mempresentasikannya di depan kelas. Kemampuan Hasil Belajar IPA pada pembelajaran konvensional di sekolah yang diteliti oleh peneliti kurang optimal dalam memberikan kesempatan siswa untuk melatih kemampuannya.

Meskipun banyak hal positif yang dikemukakan tentang model Quantum Learning tetapi dalam pembelajaran di kelas terdapat pula kendala-kendala yang ditemukan dalam pelaksanaannya. Adapun kendala-kendala yang dialami selama penelitian diantaranya, 1) dalam melakukan diskusi kelompok ada beberapa siswa yang kurang memberikan kontribusi terhadap kegiatan yang dilakukan mereka cenderung ngobrol bersama temannya, 2) pada saat penyampaian hasil kerja siswa, siswa banyak yang malu-malu untuk menyampaikan hasil mereka didepan kelas karena mereka belum terbiasa untuk berbicara di depan kelas, dan 3) pada akhir jam pelajaran pikiran siswa cenderung teralih pada situasi diluar kelas padahal belum ada pergantian jam, sehingga proses pembelajaran menjadi terganggu.

Untuk mengatasi kendala-kendala yang ditemukan tersebut, peneliti dapat mengatasinya dengan cara sebagai berikut, 1) melibatkan semua siswa dalam suatu kelompok untuk menyelesaikan tugas yang diberikan dan memberikan tanggung jawab kepada masing-masing siswa agar mau ikut 
berdiskusi dalam memecahkan masalah yang diberikan, 2) semua siswa bertanggung jawab untuk menyampaikan hasil kerja kelompoknya di depan kelas, dalam hal ini guru lebih memberikan motivasi untuk menyampaikan hasil kerja kelompoknya di depan kelas, dan 3) peneliti memberikan motivasi kepada siswa untuk tetap belajar dan membangkitkan ketertarikan siswa terhadap materi yang dibahas dengan batuan games.

Dari hasil penelitian yang telah dipaparkan di atas, secara umum telah mampu menjawab rumusan masalah yang ada, dapat dikatakan bahwa pengaruh model Quantum Learning terhadap peningkatan hasil belajar siswa kelas VII SMP Negeri 4 Singaraja pada mata pelajaran IPA. Berdasarkan hasil analisis tersebut maka dapat disimpulkan bahwa hasil belajar IPA siswa MQL dan MPK berbeda secara signifikan dimana hasil belajar IPA MQL lebih tinggi dari pada MPK baik.

\section{SIMPULAN DAN SARAN Simpulan}

Berdasarkan hasil penelitian dan pembahasan dapat dikemukakan simpulan adalah sebagai berikut. Hasil belajar IPA siswa SMP Negeri 4 Singaraja yang belajar dengan MQL berkualifikasi tinggi $(\bar{x}=84)$, sedangkan yang belajar dengan MPK nilai rata-rata juga berkualifikasi tinggi $(\bar{x}=71)$. Terdapat perbedaan yang signifikan hasil belajar antara siswa yang belajar model Quantum Learning dan siswa yang belajar dengan model pembelajaran konvensional $(F=0,000$ sig. $<0,05)$. Hasil belajar IPA siswa dengan model Quantum Learning lebih baik dari pada model pembelajaran konvensional $\left|\mu_{1}-\mu_{2}\right|>2,58$

\section{Saran}

Berdasarkan hasil penelitian ini, maka dapat diajukan beberapa saran untuk pembelajaran dan saran untuk penelitian lebih lanjut yaitu Guru sebaiknya memilih model yang sesuai, salah satunya dengan menggunakan model pembelajaran Quantum Learning. Dengan model ini, siswa akan saling bekerja sama dalam memecahkan permasalahan yang ada selama proses belajar mengajar, guru harus bisa menciptakan suasana belajar yang menyenangkan bagi siswa untuk belajar sehingga siswa akan tertarik untuk belajar, dan pada penelitian ini, materi pembelajaran yang digunakan terbatas hanya pada materi Bab II kelas VII semester genap. Oleh karena itu, peneliti menyarankan kepada peneliti selanjutnya yang ingin melakukan penelitian sejenis, untuk mengkaji materi yang berbeda dan lebih luas sehingga dapat diketahui konsistensi hasil penelitian ini.

\section{DAFTAR PUSTAKA}

Agusnanto. 2015. Penerapan Model Pembelajaran Quantum Learning Dan Model Pembelajaran Problem Based Learning Untuk Meningkatkan Hasil Belajar Siswa Pada Mata Diklat Programmable Logic Controller Di Smk Muhammadiyah 3 Yogyakarta. Skripsi Program Studi Pendidikan Mekatronika Fakultas Teknik Universitas Negeri Yogyakarta.

BBC.2015. Majalah Asia Sekolah Terbaik. Online.

http://www.bbc.com/indonesia/ma jalah/2015/05/150513 majalah a sia sekolah terbaik. diakses pada tanggal 1 november 2017

Cahyani. 2015. Pengaruh Model Pembelajaran Quantum Tipe VAK (Visual, Auditori, Kinestetik) Berbantuan Geogebra Terhadap Kemampuan Berfikir Kritis Matematika Siswa Kelas XI SMA Negeri 1 Sukawati. Skripsi (tidak diterbitkan). Singaraja: Universitas Pendidikn Ganesha.

Depdiknas. 2006. Permendiknas Nomor 22 Tahun 2006 Tentang Standar Isi. Jakarta: Depdiknas

Depdiknas. 2005. Peraturan Pemerintah RI No.19 Tahun 2005 tentang Standar Nasional Pendidikan. Jakarta: Depdiknas 
DePorter, B \& Mike, H. 2015. Quantum Learing Membiasakan Belajar Nyaman dan Menyenangkan.. Bandung: Kaifa

Katminingsih. 2012. Mengenal Revisi Taksonomi Bloom oleh Anderson dan Krathwohl.tersedia pada: filemengenal-revisi-taksonomi-

bloom-oleh.html. diakses pada tanggal desember 2018

Kemdikbud. 2017. Rekapitulasi Hasil Ujian Nasional IPA SMP/MTS SeKabupatenBuleleng.https://bulele ngkab.go.id/bankdata/hasilujiann asionalipa.html. Diakses pada tanggal 20 Desember 2017

Kemdikbud. 2016. Ilmu Pengetahuan Alam. Jakarta: Balitbang.

Kholik, M. 2011. Metode Pembelajaran Konvensional. [Online]. Tersedia pada

https://muhammadkholik.wordpre ss.com/2011/11/08/evaluasipembelajaran/. Diakses pada tanggal 25 April 2017

Moedjiono, \& Moh. Dimyati. 1994. Strategi Belajar Mengajar. Jakarta: Depdikbud Derektorat Jendral Pendidikan Tinggi Proyek Pembinaan Tenaga Kependidikan.

Pratiwi, I. 2017. Pengaruh Model Pembelajaran Quantum Learning Berbantuan Peta Konsep Terhadap Hasil Belajar Ipa Siswa Kelas V. e-journal PGSD Universitas Pendidikan Ganesha

Slavin. 2011. Psikologi Pendidikan Teori dan Praktek Edisi Kesembilan Jilid 1. Jakarta: PT Indeks

Sanjaya. 2009. Strategi Pembelajaran Berorientasi Standar Proses Pendidikan. Prenada: Jakarta.

Santyasa. 2004. Pengaruh Model dan Seting Pembelajaran Terhadap
Remidiasi,

Miskonsepsi,

Pemahaman Konsep, dan

Kompetensi Dasar IPA pada

Siswa SMU. Desertasi (tidak diterbitkan). Universitas Negeri Malang Program Pasca Sarjana.

Sari, M. 2013. Penerapan Model Quantum Learning untuk Meningkatkan Kualitas Pembelajaran Materi Energi, Panas, dan Bunyi Siswa Kelas VI Sekolah Dasar Negeri Rangdugunting 4 Kota Tegal. Skripsi Online. Tersedia pada: http://lib.unnes.ac.id/17351/1/140 9107.pdf. Diakses pada 13 Maret 2017

Sugiyono.2015. Metode Penelitian Pendidikan. Bandung: Alfabeta

Sugiyono. 2011. Statistika untuk penelitian. Bandung: alfabeta

Trianto. 2007. Model-Model Pembelajaran Inovatif Berorientasi Konstruktivistik. Jakarta: Tim Prestasi Pustaka.

Undang-undang RI Nomor 20 tahun 2003 tentang Sistem Pendidikan Nasional. Jakarta: Asa Mandiri.

Wijayanti. 2013. Pengaruh Model Pembelajaran Kuantum (Quantum Learning) Terhadap Hasil Belajar IPA Siswa Kelas V Sekolah Dasar Gugus Peliatan. Jurnal pendidikan Jurusan Pendidikan Guru Sekolah Dasar,FIP

UniversitasPendidikanGanesha

Winataputra. 2002. Materi dan Pembelajaran IPS SD. Jakarta: Universitas Terbuka

Yusuf. 2014. An Infestigation the Effect of Quantum Learning Approach in Primary School $7^{\text {th }}$ Grade Students' Scince Achievement. Retention and attitude. Educational research association the international journal of 
research in teacher education.

Tersedia pada

http://ijrte.eab.org.tr. Diakses

pada 10 maret 2017. 